\title{
Tolerable Level of Corruption for Foreign Direct Investment in Africa
}

\author{
Anselm Komla Abotsi ${ }^{1,2}$, Tongyai lyavarakul ${ }^{1}$
}

ABSTRACT

\begin{abstract}
Corruption has become endemic in many African countries and is difficult to eradicate completely; therefore, reducing corruption to a tolerable level that will not deter foreign investors must be the aspiration of all political leaders and stakeholders. This study tries to identify the level of corruption that is tolerable to foreign investors, which is referred to as the Tolerable Level of Corruption for Investment (TLCI). The study proposes that below the TLCl, corruption plays the role of "sand in the wheels of commerce" and thus has a negative impact on FDI inflows, but above the TLCl, corruption functions to "grease the wheels" and has a positive impact on FDI inflows. The study is based on secondary data collected from the World Bank World Development Indicators. Using a dynamic panel data estimation technique while controlling for other variables, the estimated TLCI in Africa is -0.27 on the control of corruption scale, which ranges from approximately - 2.5 (weak) to 2.5 (strong). Therefore, all African leaders and stakeholders, especially in countries that fall below the TLCl, should intensify their efforts in the fight against corruption to reduce corruption in their respective countries to at least the $T L C l$ to attract foreign investors.
\end{abstract}

KEY WORDS: corruption, tolerable level of corruption for investment, foreign direct investment, institutions

JEL Classification: F18, F23, F20, F30

${ }^{1}$ National Institute of Development Administration - Department of Development Economics, Bangkok, Thailand;

${ }^{2}$ University of Education, Winneba - Department of Economics, Ghana

\subsection{Introduction}

In 2013, global economic growth slowed to 2.9 percent - the lowest rate since 2009. Apart from two regions in which growth did not slow between 2012 and 2013 (South Asia and East Asia) all other regions lost momentum in growth. Labor markets have been affected by the slowdown in economic growth. The International Labour Organization (ILO, 2014) reports that $\underline{-1}$ in North Africa, the economic growth rate in 2013

Correspondence concerning this article should be addressed to: Anselm Komla Abotsi, National Institute of Development Administration - Department of Development Economics, 118 Moo3, Sereethai Road, Klong-Chan, Bangkapi, Bangkok 10240, Thailand.E-mail: agrivetent@gmail.com proved too low to generate sufficient employment opportunities for a rapidly growing population, and the unemployment rate of 12.2 percent in 2013 remained the highest in the world. The report also indicated that in sub-Saharan Africa, paid employment opportunities are scarce, and the vulnerable employment rate, 77.4 percent in 2013, remained the highest of all regions (ILO, 2014). Economic growth has traditionally been attributed to the accumulation of human and physical capital and increased productivity arising from technological innovation. It must be emphasized that economic growth, even when it is accompanied by high degree of mechanization, generates employment opportunities at least indirectly if not directly. An abundant body of literature considers the employment-GDP 
relationship (known as Okun's Law) and the employment elasticity of growth (Piacentini \& Pini, 2000; Kapsos, 2005; Seyfried, 2005). Economists generally agree that FDI inflows lead to an increased rate of economic growth (Wijeweera, Villano, \& Dollery, 2010). Particularly in developing countries, FDI inflows should exert positive effects on economic growth because these countries suffer from low productivity and capital stock deficiencies (Johnson, 2006).

Neoclassical theory predicts higher marginal returns to the factor that is relatively scarce. Thus, capital should flow from rich countries to Africa - where capital is relatively scarce. For example, the rates of return on FDI were 7 percent globally and higher in both developing (8 percent) and transition (13 percent) economies than in developed countries (5 percent) in 2012 (UNCTAD [United Nations Conference on Trade and Development], 2013). Nevertheless, the UNCTAD (2010) indicates that FDI flows into Africa decreased to $\$ 59$ billion in 2009 , which represents a 19 percent decrement. FDI flows fell further to $\$ 55$ billion in 2010, which represent 9 percent decrement, and FDI saw a third year of decline in 2011. Both economic theory and empirical studies support the notion that FDI inflows lead to future profits. Beyond the profit motive are various other factors that encourage potential foreign investors to invest in certain countries. Some of these factors include market demand conditions, trade restrictions, investment regulations, labor costs and transportation costs. Specifically, it has been argued that a strong policy and regulatory regime, appropriate institutions, good infrastructure, and political and economic stability are important for attracting FDI inflows (Mwilima, 2003). A non-policy factor that plays a role in the attraction of FDI into a country is its level of institutional quality. Most research on the effect of institutional quality on FDI inflows reveals that countries that have weak institutions, especially high corruption and unreliable legal systems, tend to receive less FDI (Gastanaga, Nugent, \& Pashamiova, 1998; Wei, 2000b). African countries still suffer from varying levels of negative perceptions from the outside world despite all the pro-FDI policies implemented to encourage FDI inflows. Factors contributing to these include corruption and political instability due to internal conflict, external conflict, military involvement in politics and religious tension. Over the years, the majority of African countries scored a 3.0 or below on the corruption perception index rating produced by Transparency International. For example, $87 \%$ of the countries in Africa scored a 3.0 or below in the years 2011, 2009 and 2008; 83\% in 2010; and 77\% in 2012. These percentages are alarming. The findings of Treisman (2000) suggest that fighting corruption in many countries has proved so difficult because it greatly varies between countries. Because of the difficulty of eradicating corruption, reducing its prevalence to a tolerable level must be the aspiration of all political leaders and stakeholders. In 2012, the number of countries that scored a 3.0 or below fell to $77 \%$. In the same the year, however, Africa reversed the downward trend in FDI, exhibiting a 5 percent increase in FDI inflows to $\$ 50$ billion. This gives an indication that there is a level of corruption that is tolerable to investors. Notwithstanding perceptions of corruption levels, FDI continues to flow to some countries, which also supports the idea of a level of corruption that is tolerable to investors. This level of corruption will likely not deter potential investors from investing in Africa. As corruption cannot be completely eradicated, reducing it below a threshold that can be accommodated by investors is a realistic goal for African leaders. In this study, this threshold is referred to as the Tolerance Level of Corruption for Investment (TLCI). This research not only seeks to establish that corruption generally has a negative impact on FDI inflows to Africa but also to show that there is a threshold (TLCI) below which corruption is expected to have a positive impact on FDI inflows to Africa. The TLCI will motivate leaders in Africa to try to control corruption in their countries to levels that will not deter FDI inflows because corruption is difficult if not impossible to eradicate completely. This will lead to an increase in economic growth and reduce both unemployment and poverty on the African continent. The TLCI will also serve as a guide for potential investors in selecting the African countries in which to invest. This study makes a further modest contribution to the empirical literature on the relationship between corruption and FDI inflows to Africa.

Using a dynamic panel data estimation technique while controlling for other variables, the estimated TLCI in Africa is -0.27 on the control of corruption scale, which ranges from approximately -2.5 (weak) 

(Dal Bo \& Rossi, 2007; Picci, 2005; Yan \& Oum, 2011). Moreover, studies elsewhere show that corruption actually deters foreign direct investment (Aizenman \& Spiegel, 2002; Barassi \& Zhou, 2012; Cuervo-Cazurra, 2006; 2008; Habib \& Zurawicki, 2002; Hakkala, Norback, \& Svaleryd, 2008; Javorcik \& Wei, 2009; Voyer \& Beamish, 2004; Wei, 2000b).

At low levels, corruption is seen as "greasing the wheels", and at high levels, it is seen as "sand in the wheels of commerce". This study argues that in countries in which bureaucratic regulations are cumbersome, corruption might be a means to achieve certain benefits by foreign investors; thus, they are motivated to invest in those countries. In such countries, corruption is expected to have a positive impact on private investment. However, when corruption goes beyond the paying of bribes to levels of malfunctioning government institutions, corruption is expected to have a negative impact on private investment. In such countries, corruption may deter foreign investment. The corruption variable is captured as the perception of corruption in the public sector of the host country and is expected to have both negative and positive effects on the inflows of FDI into a country depending on the levels of institutional quality and corruption.

\subsection{GDP growth rate and GDP per capita}

The economics literature indicates that FDI has led to economic development of the host country because FDI inflows facilitate the acquisition of valuable tangible and intangible assets, such as enhanced technology, managerial skills, expertise, innovation capability, capital formation and related physical assets (Liu, Shu, \& Sinclair, 2009; Vu, Gangnes, \& Noy, 2008; Wang, 2009). Elsewhere, market size has been predicted to be a positive and significant determinant of FDI flows (Garibaldi et al., 2002; Nunes, Oscategui, \& Peschiera, 2006; Sahoo, 2006). This is because larger consumer markets translate into more potential consumption and thus enhanced trade. Market size is generally measured by Gross Domestic Product (GDP) or GDP per capita. The real GDP growth rate is used in the literature to represent a country's economic track record and as an indicator of profitable investment opportunities (Anyanwu, 2012). On the one hand, FDI inflows cause economic growth, and on the other hand, economic growth attracts FDI inflows, thus leading to bi- causality issues and endogeneity problems. Although GDP has been used in the literature as a determinant of FDI inflows, this study intends to use the lag of the GDP growth rate, as this is a better indicator of FDI inflows to avoid endogeneity problems. Also included in the analysis is the effect of GDP per capita on FDI inflows. In this study, high previous-year GDP growth rates and GDP per capita of the host country are expected to attract more FDI.

\subsection{Trade openness}

Trade openness refers to the sum of exports and imports of goods and services into a country and gives an indication of how liberalized a country is in terms of trade. The impact of trade openness on economic growth can be positive and significant mainly due to the accumulation of physical capital and technological transfer as a result of FDI inflows. Therefore, trade openness is an important vehicle for technological spillovers. According to Eicher (1999), Lee (1993) and Young (1991), openness to trade also stimulates domestic investment by encouraging competition in domestic and international markets and generating higher returns on investment through economies of scale. Trade openness is generally a positive and significant determinant of FDI inflows (Asiedu 2002; Sahoo 2006). Trade openness is captured as trade as a share of GDP and it is expected to facilitate the flow of FDI into the host country.

\subsection{Natural resources and Political stability}

FDI attraction to Africa can also be influenced by the availability of natural resources on the continent. Jadhav (2012) suggest that resource-seeking FDI is motivated by the availability of natural resources in host countries. This resource seeking remains a relevant source of FDI for various developing countries. Studies have shown that natural resources play vital roles in overall attraction of FDI to Africa (Asiedu, 2002; 2005; Dupasquier \& Osakwe, 2006). In Africa, countries that have natural resources were more attractive than those without such resources (Asiedu, 2005). According to North and Weingast (1989) and Li (2009), democratic institutions may have a positive influence on FDI, but the presence of natural resources in host countries may affect the FDI-democracy relationship (Asiedu \& Lien, 2011). Asiedu and Lien (2011) found that democracy 
facilitates FDI inflows to countries where the share of natural resources of total exports is low, but it has a negative effect on FDI inflows to countries where exports are dominated by natural resources. This implies that the influence of natural resources and political stability on FDI has to be determined empirically.

\subsection{Economic stability and Growth prospects}

Economic stability has been found to be a positive indicator of FDI inflows (Mateev, 2009). A country that has stable macroeconomic conditions with high and sustained growth rates is expected to have more FDI inflows than a more volatile economy (Ranjan \& Agrawal, 2011). Proxies for the macroeconomic stability of a country include GDP growth rates, industrial production index values, interest rates, and inflation rates (Dasgupta \& Ratha, 2000). High inflation rates are associated with economic disarray and lower purchasing power, so inflation risk becomes an important factor in long-run investment plans. Inflation has been found to have a negative relation with FDI inflows though its magnitude is much smaller (Ranjan \& Agrawal, 2011).

However, research on the influence of exchange rates on FDI inflows has shown varied results. While Kyereboah-Coleman and Agyire-Tettey (2008) posit that the volatility of the real exchange rate has a negative influence on FDI inflows, Jeon and Rhee (2008) show that FDI inflows have significant association with both the real exchange rate and expected exchange rate changes. Nonetheless, Brahmasrene and Jiranyakul (2001) and Dewenter (1995) find no statistically significant relationship between the level of the exchange rate and FDI inflows (Anyanwu, 2012). When a country's currency depreciates, foreign investors take advantage of the ability to purchase assets at a reduced cost. Investment in countries whose currencies face high depreciation is relatively less expensive. Therefore, it is expected that a high inflation rate in the host country attracts less FDI, while higher pressure to depreciate the exchange rate of the host country attracts more FDI.

\subsection{Infrastructure facilities}

The importance of infrastructure development to attracting FDI inflows cannot be ignored. Studies by Musila and Sigue (2006) and Dupasquier and Osakwe
(2006) show that FDI in Africa is dependent on the development of infrastructure. Similar results were obtained by Kersan-Skabic and Orlic (2007) in the Western Balkan countries and Botric and Škuflić (2006) in Southeast European countries. This shows that embarking on infrastructure development provides an opportunity for countries to attract FDI inflows. Some studies (Ranjan \& Agrawal, 2011) used an infrastructure index (INFREX) constructed by considering electric power consumption (kwh per capita), energy use ( $\mathrm{kg}$ of oil equivalent per capita) and telephone lines, and these had similar results. Infrastructure in this study is captured by telephone lines per 100 population and is expected to lead to greater FDI inflows and, hence, to have a positive impact on FDI inflows.

\subsection{Methodology}

\subsection{Data}

With the exception of the control of corruption index, the variables used in this study are based on secondary data collected from the World Development Indicators for 2012. The frequency of the data is annual, and it is available from 1996 to 2012 for 50 countries in Africa. The control of corruption index is drawn from the Worldwide Governance Indicators DATABANK (World Bank, 2013b) This variable is used in determining the impact of corruption on FDI inflows to Africa. This index is chosen not only because of its authenticity but also because of its free availability on the internet. The control of corruption index is one of the six dimensions of governance included in the Worldwide Governance Indicators.

\subsection{Data Analysis}

In order to meet the objectives of the study, a dynamic panel data estimation technique is used.

Several studies have found lagged FDI to be correlated with current FDI (Asiedu, 2013), so in this study, a new estimator for dynamic panel data models based on a simple transformation of the dependent variable (FDI) is deployed. This dynamic panel model includes endogenous and exogenous variables in addition to the lagged dependent variable. The transformation is achieved by moving the lagged dependent variable to the left hand side and applying the System GMM estimator to the transformed model. The System GMM 
estimator is chosen over the Difference GMM estimator because it is consistent and asymptotically more efficient, although it is known to perform poorly in finite samples, especially when the variance ratio is high and when the dependent variable is highly persistent. The System GMM estimate also has an advantage over the Difference GMM with respect to variables that exhibit "random walk" or are close to random-walk variables (Baum, 2006; Bond, 2002; Roodman, 2006; 2007). According to Efendic, Pugh and Adnett (2009), because model specifications including macroeconomic variables are known in economics to be characterized by random walk statistical generating mechanisms, the System GMM approach seems more suitable. Empirical research with dynamic models shows that the System GMM is a good estimator, or at least better than the Difference GMM, which is severely downward biased (Hoeffler, 2002; Nkurunziza and Bates, 2003; Presbitero, 2005). Moreover, Roodman (2006) suggests that it is better to avoid Difference GMM estimation, which has a weakness of magnifying gaps if one works with an unbalanced panel.

The general model is of the form presented in equation (1).

$y_{i t}=\alpha y_{i, t-1}+x_{i t}^{\prime} \beta+\varepsilon_{i t}$

where $\varepsilon_{i t}=u_{i}+v_{i t}$, for $i=1, \ldots, \mathrm{N}$ and $t=2, \ldots, \mathrm{T}$, with $|\alpha|<1$. The disturbance term $\varepsilon_{i t}$ has two orthogonal components, which are the fixed effects $u_{i}$ and the idiosyncratic shocks $v_{i t}$. $E\left(u_{i}\right)=E\left(v_{i t}\right)=E\left(u_{i} v_{i t}\right)=0$ for $i=1, \ldots, \mathrm{N}$ and $t=2, \ldots, \mathrm{T}$.

The framework for evaluating the associations among FDI, corruption, and other determinants of FDI is presented in equation (2).

$y_{i t}=\beta_{1}+\beta_{2} x_{i t}+\beta_{3} x_{i t}^{2}+\omega z_{i t}+\alpha_{1} y_{i, t-1}+\varepsilon_{i t}$

where $y_{i t}$ is a measure of FDI in country $i$ at time period $t, y_{i, t-1}$ is a measure of FDI in country $i$ at time period $t-1, x_{i t}$ is an index of the control of corruption in country $i$ at time $t, x_{i t}^{2}$ is the squared index of control of corruption in country $i$ at time period $t, z_{i t}$ are control variables in country $i$ at time period $t, \beta_{1}, \beta_{2}$, $\beta_{3}, \alpha_{1}$ and $\omega$ are parameters to be estimated, and finally, $\varepsilon_{i t}$ denotes the disturbance term. StataCorp 2013 is the statistical software used in the data analysis.

\subsection{Model One: The System GMM Model of FDI}

The benchmark FDI equation in a linear form, with a constant term, is presented in equation (3).

$F D I_{-}$PerGDP $P_{i t}=$

$=\beta_{1}+\beta_{2}$ Control_of_Corruption ${ }_{i t}+$

$+\beta_{3}$ Control_of_Corruption_Sqrit +

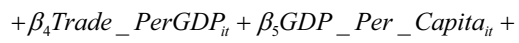

$+\beta_{6}$ Natural_resource $_{i t}+\beta_{7}$ Political_stability $_{i t}+$

$+\beta_{8}$ Inflation_Consum_Prices ${ }_{i t}+$

$+\beta_{9}$ Exchange_Rate_PerUS $S_{i t}+$

$+\beta_{10} G D P$ Growth_PerAnnual $_{i t-1}+$

$+\beta_{11}$ Telephone_lines ${ }_{i t}+\beta_{12} F D I \_$PerGDP $P_{i t-1}+$

+ Time $($ Dummies $)+\varepsilon_{i t}$

The net FDI inflow per GDP is used as the dependent variable in the estimation of the system dynamic model. In addition to the variable of interest, control of corruption and its squared values are included as independent variables, and other control variables were carefully chosen based on previous research and data availability for the selected period. These control variables include trade openness, GDP per capita, natural resources, political stability, inflation rate, exchange rate, the lag of GDP growth rate and telephone lines per 100 population of the host countries. To find out whether FDI inflow to Africa was affected by timerelated shocks, time dummies were included.

The control of corruption variable is defined as perceptions of the extent to which public power is exercised for private gain, including both petty and grand forms of corruption, as well as "capture" of the state by elites and private interests (World Bank, 2013b). The control of corruption variable is transformed from its original scale, which ranges from approximately -2.5 (weak) to 2.5 (strong), to a new scale ranging from 0 to 100 for computational purposes and to allow for easy interpretation of the results. The following formula was used: $x=(a+2.5) * 20$, where $x$ is value of the transformed variable, and $a$ refers to the value of the original scale. This means that the higher a country is on the scale, the better the governance performance against corruption and thus the lower the level of corruption. Therefore, countries scoring low on the scale are relatively more corrupt. A similar transformation was performed for the political stability index, which 'reflects perceptions of the likelihood that the 
Table 1. Correlation Matrix of Variables used in the Study

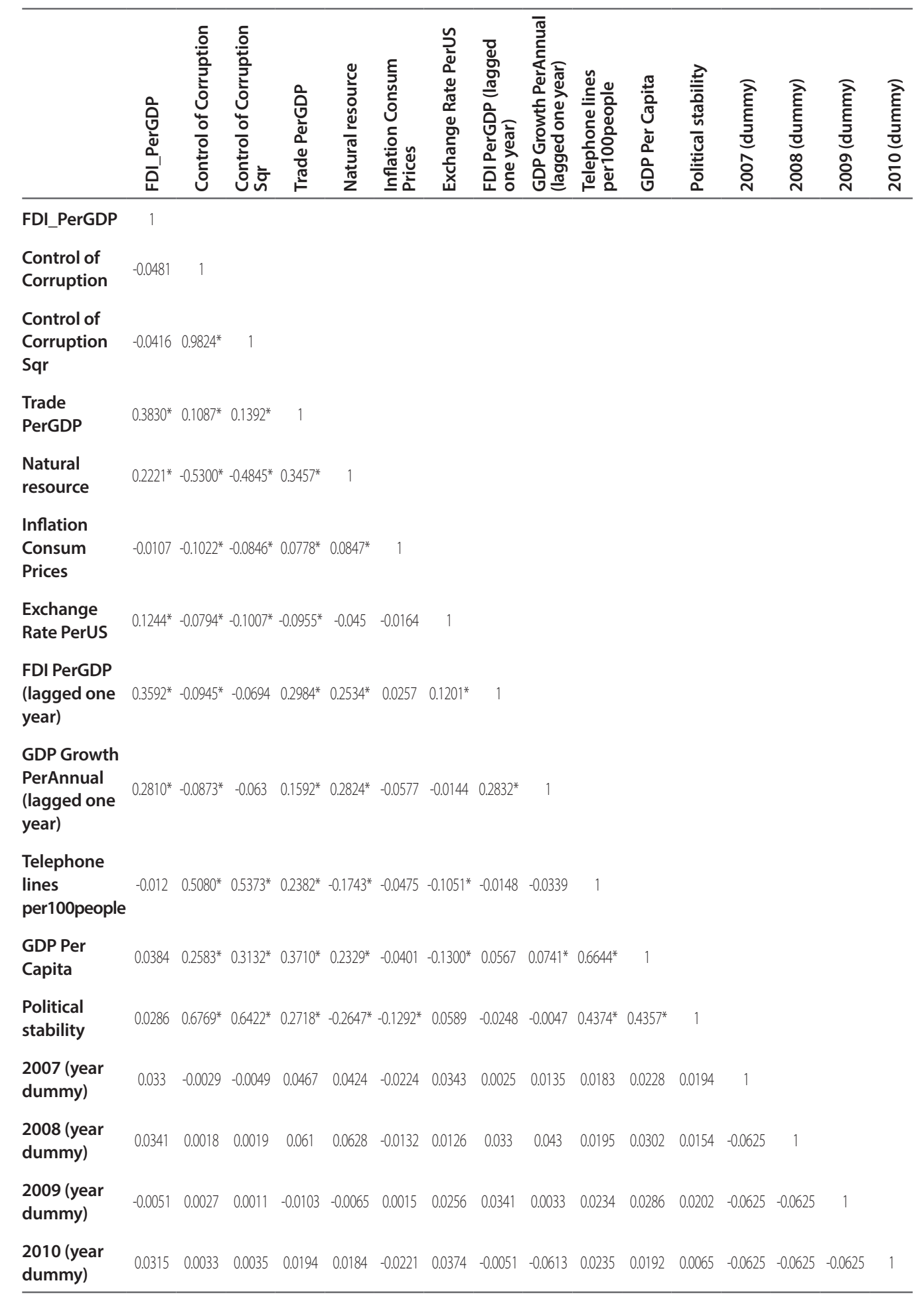


government will be destabilized or overthrown by unconstitutional or violent means, including politically motivated violence and terrorism' (World Bank, 2013b). Trade openness refers to the sum of exports and imports of goods and services measured as a share of the gross domestic product. Natural resources refer to total natural resource rents, which include the sum of oil, natural gas, coal (hard and soft), mineral, and forest rents. Inflation, as measured by the consumer price index, reflects the annual percentage change in the cost to the average consumer of acquiring a basket of goods and services that may be fixed or changed at specified intervals. The official exchange rate refers to the exchange rate determined by national authorities or to the rate determined in the legally sanctioned exchange market. It is calculated as an annual average based on monthly averages (local currency units relative to the U.S. dollar). GDP growth rate refers to annual percentage growth rate of GDP at market prices based on constant local currency, and the aggregates are based on constant 2005 U.S. dollars. Telephone lines are fixed telephone lines that connect a subscriber's terminal equipment to the public switched telephone network and that have a port on a telephone exchange. Finally, GDP per capita is the gross domestic product divided by the midyear population (World Bank, 2013a). The correlation matrix (Table 1) indicates significant correlations among some independent variables. It is expected that the existence of correlations among the independent variables will lead to multicollinearity in the estimation, but the statistical nature of panel data estimation addresses the collinearity problems (Ranjan \& Agrawal, 2011). Therefore, the inclusion of these variables in the model would not increase the variance of the coefficient estimates because this will render the coefficient estimates unstable.

The two-step estimator is deployed in the estimation because the standard covariance matrix is robust to panel-specific autocorrelation and heteroskedasticity and is thus asymptotically efficient. Control of corruption and trade openness are treated as endogenous and all other independent variables as strictly exogenous. The endogeneity of these variables is controlled for by including their lagged forms as regressors by using internal instruments (lagged levels and lagged differences). It is also less probable that control of corruption and trade openness explain changes in the other independent variables strictly treated as exogenous. No external instruments are used. In this panel, there are 50 countries $(\mathrm{N})$ that are analyzed over a period of 17 years $(\mathrm{T})$, which means there are more countries (N) than years (T). It has been argued by many authors that dynamic panel models are especially designed for situations wherein $\mathrm{T}$ is smaller than $\mathrm{N}$ to control for dynamic panel bias (Baltagi, 2008; Baum, 2006; Bond, 2002; Roodman, 2006; 2007; Sarafidis, Yamagata, \& Robertson, 2009).

\subsection{Dynamic Panel Model}

Nerlove (2002) argues that economic behavior is inherently dynamic, and thus, most econometrically interesting relationships are explicitly or implicitly dynamic. A simple dynamic model regresses $y_{i t}$ on polynomial in time. Adjustment might be partial: the current year's outcome depends on the previous year's outcome, i.e., includes lags of $y$. Bond (2002) is of the view that when coefficients on the lagged dependent variables are not of direct interest, allowing for dynamics in the underlying process may be crucial for recovering consistent estimates for the other parameters. The inclusion of lags of dependent variables is a parsimonious way of accounting for the effects of explanatory variables in the past and can also help to remove serial correlation in the disturbance term (Beck \& Katz, 1996). Dynamic panel models are useful when the dependent variable depends on its own past realizations. In addition, models including lagged dependent variables can also control, to a large extent, for many omitted variables.

Once a lagged dependent variable is included as part of the panel model specification, there is a violation of strict/strong exogeneity because the lagged dependent variable, which is one of the regressors, is correlated with past values of the error term. The correlation of the idiosyncratic error term $v_{i t}$ with the lagged dependent variable $y_{i, t-1}$ at time $\mathrm{t}+2$ is the source of the strict exogeneity. There is also a violation of the weaker condition of no contemporaneous correlation of the regressors with the composite error term $\left(\varepsilon_{i t}=u_{i}+v_{i t}\right)$. When $y_{i t}$ is correlated with the fixed effects in the error term, it gives rise to "dynamic panel bias" (Nickell, 1981). The endogeneity problem renders the estimators inconsistent and inferences from the estimated model less accurate. 


\subsection{The GMM Estimator}

The panel dynamic model takes the following form (equation (4)) where $y$ exhibit state dependence:

$y_{i, t}=\alpha y_{i, t-1}+\beta^{\prime} x_{i, t}+\varepsilon_{i, t}$

where $\varepsilon_{i t}=u_{i}+v_{i, t}, E(\varepsilon \mid Z)=0, \beta$ is a column vector of coefficients, $y$ and $\varepsilon$ are random variables, $x$ is a column vector of $\mathrm{k}$ regressors, $z$ is column vector of $\mathrm{j}$ instruments, and $j \geq k$. $\mathrm{X}, \mathrm{Y}$, and $\mathrm{Z}$ represent matrices of $\mathrm{N}$ observations for $x, y$ and $z$, respectively. The empirical residuals are $\hat{\mathrm{E}}=Y-X \hat{\beta}$. According to Roodman (2009), the problem in estimating this model is that all the instruments are theoretically orthogonal to the error term, which means $E(z \varepsilon)=0$. Forcing the corresponding vector of empirical mo-

ments $E_{N}(z \varepsilon) \equiv\left(\frac{1}{N}\right) Z^{\prime} \hat{E}$ to zero generates a system with more equations than variables if $j>k$. This renders the specification over-identified.

The solution to this problem in econometrics is normally the use of instrumental variables (IV). Roodman (2009) suggest two ways to solve this endogeneity problem. One is the use of Difference Generalized Method of Moments (D-GMM) to transform the data to eliminate the fixed effects. The Difference GMM refers to the removal of the individual-specific and unobserved effect in a dynamic panel model by taken the first difference of the linear dynamic panel regression. The sequential exogeneity and the zero serial and cross-section correlation of $\varepsilon_{i t}$ in the firstdifferenced linear dynamic panel regression imply that moment conditions $E\left(y_{i, t-s} \Delta \varepsilon_{i t}\right)=0$ for all $i, t$ and $s=2, \ldots \ldots, \infty$ hold. The past levels of the dependent variable serve as instruments for the current first differences of the dependent variable. Difference GMM (D-GMM) is ascribed to Arellano and Bond (1991). The other is the use of System Generalized Method of Moments (S-GMM) to instrument the lag of the dependent variable $y_{i, t-1}$ as well as any other similarly endogenous variables with variables that are uncorrelated with the fixed effects. The System GMM follows the Difference GMM estimation procedure with an additional assumption $\left(E\left(\Delta y_{i, t-s}\left[\alpha_{i}+\varepsilon_{i t}\right]\right)=0\right.$ for all $i, t$ and $s=2, \ldots \ldots, \infty)$, leading to an additional set of moment conditions to leverage. System GMM
(S-GMM) is ascribed to Blundell and Bond (1998). S-GMM therefore necessitates lagged changes in the dependent variable to be valid instruments for the level of the lagged dependent variable in the level equation. Though more assumptions are involved with System GMM than Difference GMM, System GMM achieves greater efficiency once these assumptions hold. Moreover, because the System GMM uses the level version of the dynamic panel model together with the differenced version, the effects of time-invariant regressors can be estimated in contrast to Difference GMM in which they are differenced out. The system estimator uses the first difference of all the exogenous variables as standard instruments and the lags of the endogenous variables to generate the GMM-type instruments as described in Arellano and Bond (1991) and includes lagged differences of the endogenous variables as instruments for the level equation.

\subsection{Specification Testing in Dynamic Panel Models}

Specification testing in dynamic panel models is conducted to address problems of over-identification restrictions and serial correlation. This is accomplished by using the standard Sargan and Hansen J test for over-identification restrictions and Arellano-Bond test for autocorrelation. Roodman (2009) explains that if the model is over-identified, a test statistic for the joint validity of the moment conditions falls out of the GMM framework. The vector of empirical mo-

ments $\left(\frac{1}{N}\right) Z^{\prime} \hat{E}$ is randomly distributed over 0 under the null of joint validity. Under the null hypothesis that all instruments are uncorrelated with $u$, the test has a large-sample $\chi^{2}(r)$ distribution, where $r$ is the number of over-identifying restrictions. The null in both of these tests is that all of the instruments are valid and the alternative is that some subsets are not valid. Roodman (2009) indicates that Sargan-Hansen statistics can also be used to test the validity of subsets of instruments via a "difference-in-Sargan/Hansen" test, which is also known as a $\mathrm{C}$ statistic. The Sargan-Hansen test reports two test statistics after estimation - with and without a subset of suspect instruments under the null of joint validity of the full instrument set. 


\subsection{Testing for Residual Serial Correlation}

The degree of serial correlation of the residual term in either Difference GMM or System GMM will determine the validity of any instruments used based upon the dependent variable. The set of valid instruments based upon the dependent variable changes once the residual term is serially correlated. The lags of the change in the dependent variable greater than or equal to 1 are valid instruments for the level equation with the System GMM framework and lags of the dependent variable greater than or equal to 2 are valid instruments for the differenced equation with the Difference GMM framework. The full disturbance term $\left(\varepsilon_{i t}=u_{i}+v_{i t}\right)$ contains fixed effects and is presumed autocorrelated, so the estimators are designed to remove this source of problem. If the $\varepsilon_{i t}$ are serially independent, then $E\left(\Delta \varepsilon_{i t} \Delta \varepsilon_{i t-1}\right)=E\left[\left(\varepsilon_{i t}-\varepsilon_{i t-1}\right)\left(\varepsilon_{i t-1}-\varepsilon_{i t-2}\right)\right]=-E\left[\varepsilon_{i t-1}^{2}\right]=-\sigma_{\varepsilon}^{2}$. Thus, first order serial correlation would be expected. It is, however, not expected that there be any second order serial correlation, (i.e., $E\left(\Delta \varepsilon_{i t} \Delta \varepsilon_{i t-2}\right)=$ $=E\left[\left(\varepsilon_{i t}-\varepsilon_{i t-1}\right)\left(\varepsilon_{i t-2}-\varepsilon_{i t-3}\right)\right]=0$. One should therefore test for second order serial correlation because its presence indicates a specification error. The idiosyncratic disturbance term $v_{i t}$ is related to $\Delta v_{i, t-1}$ mathematically via the shared $v_{i, t-1}$ term, so a negative first order serial correlation is expected in differences meaning that its evidence is of no importance. Therefore, to check for first order serial correlation in levels, it is important to check for second order correlation in differences as well, as this will detect correlation between the $v_{i, t-1}$ in $\Delta v_{i t}$ and the $v_{i, t-2}$ in $\Delta v_{i, t-2}$. Therefore, serial correlation of order $l$ in levels is checked by looking for correlation of order $l+1$ in difference (Roodman, 2009). These tests lose power when the number of instruments $i$ is large relative to the cross section sample size $n$. The rule of thumb is to keep the number of instruments less than or equal to the number of groups so that when the ratio $r$ of the sample size to the number of instruments is less than one, ratio $=\frac{n}{i}<1$, the assumptions underlying the two procedures may be violated.

\subsection{The Estimation of Tolerable Level of Corruption for Investment}

Relationships between two economic variables are predicted to be non-monotonic in various economic theories. A popular empirical test of such theories, accord- ing to Plassmann and Khanna (2003), is to estimate an equation using a polynomial of the variable that is supposed to have the non-linear relationship. Once the estimated turning point of the equation is well within the range of the data, this is an indication that the true relationship is non-monotonic. To empirically estimate the Tolerable Level of Corruption for Investment, a power term of the control of corruption index is introduced into the dynamic model to estimate the level of corruption that attracts FDI inflows to Africa. With the addition of the quadratic term, one bend is modeled in the regression. The response variable in this study is foreign direct investment, net inflows (\% of GDP) labeled as FDI PerGDP and the variables, Control of Corruption and Control of Corruption Sqr are the control of corruption index and its square, respectively. The TLCI is obtained by estimating the equation and taking the derivative of the estimated equation with respect to the control of corruption variable. Suppose the following is the estimated equation (5):

$\hat{y}_{i t}=\hat{\beta}_{1}+\hat{\beta}_{2} x_{1}+\hat{\beta}_{3} x_{1}^{2}+\ldots$

where $\hat{\beta}_{2}$ and $\hat{\beta}_{3}$ are estimators of the parameters $\beta_{2}$ and $\beta_{3}$, respectively. Taking the derivative w.r.t. $x_{1}$ yields equation (6):

$\frac{\delta \hat{y}_{i t}}{\delta x_{1}}=\hat{\beta}_{2}+2 \hat{\beta}_{3} x_{1}=0$

Solving this equation gives the turning point of the relationship reflecting an inverse $U$-shape if $\hat{\beta}_{2}<0$ and vice versa. The coefficient $\hat{\beta}_{3}$ tells both the direction and steepness of the curvature (a positive value indicates the curvature is upwards while a negative value indicates the curvature is downwards). This means that the turning point is given by $\varphi=-\frac{\hat{\beta}_{2}}{2 \hat{\beta}_{3}}$, which is referred to as the threshold point or the Tolerable Level of Corruption for Investment.

\subsection{Test of the U-Shaped Relationship}

The control of corruption variable scale ranges from approximately -2.5 (weak) to 2.5 (strong), which means that the higher a country is on the scale, the better governance performance against corruption and, thus, the smaller the level of corruption. Therefore, 
countries scoring low on the scale are relatively more corrupt and expected to attract less FDI, and countries scoring high on the scale are relatively less corrupt and thus expected to attract more FDI. Therefore, at low scores, corruption is expected to have negative impact on FDI inflow, and at high scores, corruption is expected to have a positive impact on FDI inflow. This accounts for the U-shaped relationship.

Most works on turning points use the criteria that if both $\hat{\beta}_{1}$ and $\hat{\beta}_{2}$ are significant and if the implied extreme point is within the data range, then they have found a $\mathrm{U}$-shaped relationship. Lind and Mehlum (2007) hold these criteria as sensible but postulate that they are neither sufficient nor necessary and argue that these criteria are too weak. According to Lind and Mehlum (2007), to properly test for the presence of a U-shaped relationship on some interval of values, we need to test whether the relationship is decreasing at low values within this interval and increasing at high values within the interval. Assuming that $\varepsilon_{i t} \sim \operatorname{NID}(0, \sigma 2)$, a test based on likelihood ratio principle (Sasabuchi, 1980) takes the form:

For $\min (\mathrm{x})$

$$
\begin{array}{ll}
H_{0}: & \beta_{2}+\beta_{3} f^{\prime}\left(x_{l}\right) \geq 0 \\
H_{1}: & \beta_{2}+\beta_{3} f^{\prime}\left(x_{l}\right)<0
\end{array}
$$

For $\max (\mathrm{x})$

$$
\begin{array}{ll}
H_{0}: & \beta_{2}+\beta_{3} f^{\prime}\left(x_{h}\right) \leq 0 \\
H_{1}: & \beta_{2}+\beta_{3} f^{\prime}\left(x_{h}\right)>0
\end{array}
$$

Rejection of the null hypotheses in both cases is a confirmation of a U-shaped relationship. This test gives the exact necessary and sufficient conditions for the test of a $U$ shape. An equivalent test, according to Lind and Mehlum (2007), involves constructing a confidence interval for the minimum point and determining whether the confidence interval is contained within the interval $\left[x_{l}, x_{h}\right]$. Both tests will be used in this study to confirm a U-shaped relationship and hence the threshold point or the Tolerable Level of Corruption for Investment.

\subsection{Results}

\subsection{Descriptive statistics}

The descriptive statistics of the variables deployed in the study are presented in Table 2. All the variables have values ranging from 727 to 877 , as the highest observations. The period under study is from 1996 to 2012. Variables obtained from Worldwide Governance Indicators (control of corruption and political stability) have data missing for three years $(1997,1999$, \& 2001), and this accounts for those variables having the lowest number of observations. Telephone lines have highest number of observations, which gives an indication of the level of infrastructure development in Africa. The mean GDP per capita is 1688.28 , and the standard deviation is 2591.61 , which shows that the observations are widely dispersed. Also worthy of mention are the mean exchange rate (714.10) and standard deviation of 1857.42, which shows high fluctuation of exchange rate within the period of observation. The mean of inflation rate is 20.10 , and the standard deviation of 158.95 also indicates high fluctuation of inflation rate within the period of observation. The variables with the lowest dispersion include FDI inflow, control of corruption, trade openness, natural resource, GDP growth and telephone lines.

\subsection{Empirical Results of the Dynamic Panel Model}

The results of the dynamic panel model estimated including endogenous and exogenous variables in addition to the lagged dependent variable are presented in Table 3. The FDI net inflow per GDP is used as the dependent variable in the estimation of the FDI model. The control of corruption variable and its squared values as well as other control variables are used as independent variables. The two-step estimator is deployed in the estimation, with control of corruption and trade openness variables treated as endogenous and all other independent variables treated strictly as exogenous. No external instruments are used.

\subsection{Model Specification Diagnostics Test}

The validity of the estimated results in System GMM depends on the statistical diagnostics tests. The results indicate that the specification pass the Hansen J-statistic test for Over-Identifying Restrictions 
Table 2. Descriptive Statistics of Variables in the Dynamic Model

\begin{tabular}{lccccc}
\hline Variable & Observation & Mean & Std. Dev. & Min & Max \\
\hline FDI PerGDP & 805 & 4.874661 & 10.38533 & -82.8921 & 145.202 \\
Control of Corruption & 727 & 38.05282 & 11.91438 & 8.800001 & 75 \\
Control of Corruption Sqr & 727 & 1589.774 & 994.3457 & 77.44002 & 5625 \\
Trade PerGDP & 797 & 77.11778 & 37.27615 & 17.85861 & 275.2324 \\
Natural resource & 863 & 15.36953 & 18.02374 & 0.003196 & 100.3669 \\
Inflation Consum Prices & 797 & 20.9961 & 158.9528 & -9.79765 & 4145.107 \\
Exchange Rate PerUS & 859 & 714.0977 & 1857.418 & 0.010014 & 19068.42 \\
FDI PerGDP (lagged one year) & 805 & 4.874661 & 10.38533 & -82.8921 & 145.202 \\
GDP Growth PerAnnual (lagged one year) & 848 & 4.807308 & 7.160985 & -32.8321 & 106.2798 \\
Telephone lines per100people & 877 & 3.499723 & 5.821433 & 0.000236 & 33.11384 \\
GDP Per Capita & 851 & 1688.275 & 2591.605 & 53.09856 & 14901.35 \\
Political stability & 728 & 38.95907 & 19.05746 & -16.4 & 73.8 \\
\hline
\end{tabular}

(OIR), confirming that the instrument can be considered valid. If the model is well specified, it is expected that the null hypothesis of no autocorrelation of the second order $\operatorname{AR}(2)$ is not rejected, and therefore, the Arellano-Bond test for serial correlation supports the validity of the model specification (Basu, 2008). As the number of instruments (47) is less than the number of groups (50), the assumptions underlying the two procedures are not violated. The 47 instruments came from the restriction to use two lags for levels and two for differences in the data (i.e., the restriction is set to (2 2) in xtabond2).

The two-step estimates that report the Hansen Jstatistic test yield theoretically robust results (Roodman, 2006). The Hansen J-statistic tests the null hypothesis of correct model specification and valid over-identifying restrictions, i.e., the validity of instruments. The rejection of the null hypothesis means that either or both assumptions are violated. Baum (2006) argues that the Hansen J-test is the most commonly used diagnostic in GMM estimation for assessment of the suitability of the model. The Hansen J-test of over-identifying restrictions does not reject the null at any conventional level of significance ( $p=0.188$ ), giving an indication that the model has valid instrumentation. The difference-in-Sargan/Hansen test, also known as the C-test (Baum 2006; Roodman, 2006), is used to test the validity of subsets of instruments (i.e., levels, differenced, and standard IV instruments). It estimates the System GMM with and without a subset of suspect instruments enabling investigation of the validity (i.e., exogeneity) of any subset of instruments as well as their contribution to "the increase in J-test" (Roodman, 2007). The null hypothesis of the model diagnosis test, which states that the specified variables are proper instruments, i.e., the set of examined instruments is exogenous with p-value 0.471 for GMM differenced instruments and 0.137 for system instruments cannot be rejected. This shows that the exogeneity of any GMM instruments used, i.e., levels and differenced instruments, are valid instruments. Similarly, the null hypothesis of the model diagnosis test states that the specified variables are proper standard "IV" instrument subsets cannot be rejected.

Efendic et al. (2009) posits that the check for the "steady state" assumption suggested by (Roodman, 

Table 3. Results of the Dynamic System GMM Estimation

\begin{tabular}{|c|c|}
\hline VARIABLES & FDI_PerGDP \\
\hline Control of Corruption & $\begin{array}{l}-0.533^{* * *} \\
(0.142)\end{array}$ \\
\hline Control of Corruption Sqr & $\begin{array}{l}0.00599^{* * *} \\
(0.00146)\end{array}$ \\
\hline Trade PerGDP & $\begin{array}{l}0.0413^{* * *} \\
(0.00708)\end{array}$ \\
\hline Natural resource & $\begin{array}{l}0.0154 \\
(0.0141)\end{array}$ \\
\hline Inflation Consum Prices & $\begin{array}{l}-0.0159^{* * *} \\
(0.00323)\end{array}$ \\
\hline Exchange Rate PerUS & $\begin{array}{l}0.000689^{* * *} \\
(4.19 e-05)\end{array}$ \\
\hline FDI PerGDP (lagged one year) & $\begin{array}{l}0.468^{* * *} \\
(0.0133)\end{array}$ \\
\hline GDP Growth PerAnnual (lagged one year) & $\begin{array}{l}0.0154^{* *} \\
(0.00757)\end{array}$ \\
\hline Telephone lines per100people & $\begin{array}{l}0.0262 \\
(0.0538)\end{array}$ \\
\hline GDP Per Capita & $\begin{array}{l}-0.000370^{* * *} \\
(8.92 \mathrm{e}-05)\end{array}$ \\
\hline Political stability & $\begin{array}{l}0.00470 \\
(0.0159)\end{array}$ \\
\hline 2007 (dummy) & $\begin{array}{l}1.225^{* * *} \\
(0.167)\end{array}$ \\
\hline 2008 (dummy) & $\begin{array}{l}0.904^{* * *} \\
(0.205)\end{array}$ \\
\hline 2009 (dummy) & $\begin{array}{l}-0.793^{* * *} \\
(0.158)\end{array}$ \\
\hline 2010 (dummy) & $\begin{array}{l}0.911^{* * *} \\
(0.189)\end{array}$ \\
\hline Constant & $\begin{array}{l}9.905^{* * *} \\
(3.058)\end{array}$ \\
\hline
\end{tabular}


Table 3. Results of the Dynamic System GMM Estimation (Continued)

\begin{tabular}{ll}
\hline VARIABLES & FDI_PerGDP \\
\hline OIR test (p-value) & 0.188 \\
Arellano-Bond test for AR(1) & 0.059 \\
Arellano-Bond test for AR(2) & 0.331 \\
Number of instruments & 47 \\
Observations & 537 \\
Number of groups & 50 \\
\hline
\end{tabular}

Note: Standard errors in parentheses

*** $p<0.01,{ }^{* *} p<0.05,{ }^{*} p<0.1$

can also be thought of as a proxy for labor costs, this means foreign investors desire countries with relatively cheap labor costs. Alsan, Bloom and Canning (2006) posits that GDP per capita may reflect both market size and cost effects. The exchange rate is found, as expected, to have positive impact on FDI inflows. The results show that a 1-unit increase in exchange rate leads to $0.07 \%$ increase in the percentage of FDI inflow to GDP in the host country. High exchange rate value relative to the US dollar in the host country accrue to the advantage of the foreign investor because this implies a depreciated currency leads to reduced cost of investment in the host country. It is worth mentioning that natural resources, telephone lines (infrastructural development) and political stability, although not significant, have the expected sign.

The global economy experienced a severe recession inflicted by a massive financial crisis and acute loss of confidence in 2009. Economies around the world have been seriously affected by the financial crisis and slump in activity. FDI inflows to Africa have suffered recently in the wake of the global economic crisis. To determine whether FDI inflow to Africa was affected by time-related shocks, time dummies were included. The inclusion of time dummies in the specification is likely to improve the statistical diagnostics as a result of potential heterogeneous cross-section dependence and also to remove universal time-related shocks from the error term (Efendic et al., 2009; Sarafidis et al., 2009). The time dummy variables used to capture uni- versal time-related shocks before and after the global economy recession are mainly significant. The dummy for 2009 is negative and highly statistically significant, and this finding suggests that FDI inflow to Africa suffered a time-related shock in 2009 due to the severe global economic recession.

\subsection{The estimated Tolerable Level of Corruption for Investment}

The results in Table 4 show that at certain level of corruption of the host country, investors are motivated to invest in that country, but below that level, investors decline to invest in that country. Estimating the level of corruption that is likely to attract potential investor to Africa is very important not only to African leaders but to all (new and old) potential investors in Africa. This level of corruption is the TLCI of a country, which will determine whether FDI is likely to flow to a country. The coefficient $\hat{\beta}_{2}$ of the control of corruption variable tells both the direction and steepness of the curvature. As $\hat{\beta}_{2}$ is a positive value, it indicates that the curvature is upwards but less steep. The turning point is 44.51 , and it is highly statistically significant with $95 \%$ confidence interval between 37.20 at the minimum and 51.81 at the maximum, as shown in Table 4.

Before the turning point can be used for any analysis, it is prudent to test for its precision and ensure its robustness. The usual criteria used by most researchers is that if both $\hat{\beta}_{1}$ and $\hat{\beta}_{2}$ are significant and if the 
Table 4. The Turning Point Estimate

\begin{tabular}{lcccccc}
\hline FDI_PerGDP & Coef. & Std. Err. & $\mathbf{z}$ & $\mathbf{P}>\mathbf{z}$ & [95\% Conf. Interval] \\
\hline Turning point & 44.50556 & 3.726251 & 11.94 & 0.000 & 37.20225 & 51.80888 \\
\hline
\end{tabular}

Table 5. Joint Hypothesis Test Results

\begin{tabular}{cc}
\hline FDI_PerGDP & Coefficient \\
\hline$H_{0}: \beta_{1}+\beta_{2} f^{\prime}\left(x_{l}\right) \geq 0$ & $-0.42765^{* * *}$ \\
& $(0.1184)$ \\
$H_{0}: \beta_{1}+\beta_{2} f^{\prime}\left(x_{h}\right) \leq 0$ & $0.365239^{* * *}$ \\
\hline
\end{tabular}

Note: Standard errors in parentheses

${ }^{* * *} p<0.01,{ }^{* *} p<0.05,{ }^{*} p<0.1$

implied extreme point is within the data range, then they have found a U-shaped relationship. This test is satisfied in this study because the results in Table 3 show both the control of corruption and the square of control of corruption are significant. However, these criteria, though sensible, are neither sufficient nor necessary and are too weak, as argued by Lind and Mehlum (2007).

Lind and Mehlum (2007) posit that to properly test for the presence of a $\mathrm{U}$-shaped relationship, on some interval of values, we need to joint test whether the relationship is decreasing at low values within this interval and increasing at high values within the interval. The results of the combined test (Table 5) with null hypothesis $H_{0}: \beta_{1}+\beta_{2} f^{\prime}\left(x_{l}\right) \geq 0$ and/or $\beta_{1}+\beta_{2} f^{\prime}\left(x_{h}\right) \leq 0$ rejects the null hypothesis and confirms a U-shaped relationship on the observed data range. This test gives the exact necessary and sufficient conditions for the test of a $\mathrm{U}$ shape. The confidence interval $(37.20225 \leq \varphi \leq 51.80888)$ for the turning point is contained within the observed data range, which further confirms this U-shaped relationship.

Once the exact necessary and sufficient conditions for the test of a U-shaped relationship are satisfied, it can be safely stated that the estimated TLCI for Africa is 44.51 . This figure translates to -0.27 on the original control of corruption scale, which ranges from approximately -2.5 (weak) to 2.5 (strong). This means that all African countries falling below the TLCI (the figure -0.27) are less likely to attract FDI inflow. All the countries falling below the TLCI are above the threshold of corruption, and those falling above the TLCI are conversely below the threshold of corruption. This result shows that corruption has a negative effect on FDI when corruption is below the TLCI and a positive effect when above. This finding seems to support the finding by Cuervo-Cazurra (2008) that pervasive corruption has a larger negative influence on FDI in transition economies, while arbitrary corruption has a lower negative influence on FDI. Specifically, the findings in this study are consistent with research by Cole, Elliott and Zhang (2009) on the determinants of province-level FDI in China, which found that foreign capital prefers to locate in regions in which the government has made more effort to fight corruption and the local government is considered to be more efficient. Barassi and Zhou (2012) used non-parametric methods to show that 
Table 6. Countries with Corruption Level above TLCI

\begin{tabular}{|c|c|c|c|c|c|c|c|}
\hline 2009 & index & 2010 & index & 2011 & index & 2012 & index \\
\hline Botswana & 0.92 & Botswana & 1.00 & Botswana & 0.99 & Botswana & 0.94 \\
\hline Cape Verde & 0.77 & Cape Verde & 0.80 & Cape Verde & 0.87 & Cape Verde & 0.81 \\
\hline Ghana & 0.03 & Ghana & 0.06 & Ghana & 0.05 & Ghana & -0.09 \\
\hline Lesotho & 0.16 & Lesotho & 0.18 & Lesotho & 0.18 & Lesotho & 0.11 \\
\hline Madagascar & -0.19 & Mauritius & 0.65 & Mauritius & 0.59 & Mauritius & 0.33 \\
\hline Mauritius & 0.63 & Morocco & -0.18 & Namibia & 0.31 & Namibia & 0.32 \\
\hline Namibia & 0.25 & Namibia & 0.32 & Rwanda & 0.43 & Rwanda & 0.66 \\
\hline Rwanda & 0.13 & Rwanda & 0.46 & Seychelles & 0.26 & Seychelles & 0.33 \\
\hline Seychelles & 0.31 & Seychelles & 0.29 & South Africa & 0.04 & South Africa & -0.15 \\
\hline South Africa & 0.14 & South Africa & 0.09 & Tunisia & -0.22 & Tunisia & -0.18 \\
\hline Swaziland & -0.20 & Swaziland & -0.17 & & & & \\
\hline Tunisia & -0.11 & Tunisia & -0.15 & & & & \\
\hline
\end{tabular}

the impact of corruption on FDI stock is not homogenous. The results of this study complement the findings of Barassi and Zhou (2012), which show that for the top percentile of FDI stock distributions, the impact of corruption on FDI may not be negative after controlling for other relevant factors, such as MNEs' location choice, market size, and factor costs between 1996 and 2003.

In 2009 and 2010, twelve countries exhibited corruption levels above the TLCI, but this number was reduced to 10 in 2010 and 2012 (Table 6). Madagascar fell out in 2010, 2011 and 2012, while Morocco appeared only in 2010. These countries are within the Southern, Western, Eastern and Northern African regions. Conspicuously missing is the Central or Middle Africa region. This finding therefore serves as a wakeup call to all countries below the TLCI to intensify their efforts to reduce the level of corruption in their respective countries to at least the TLCI. The confidence interval (37.20225 $\leq \varphi \leq 51.80888)$ for the TLCI translates to $(-0.64 \leq \varphi \leq 0.09)$ on the original control of corruption scale. Therefore, countries that fall within this range can be referred to as transition countries.

\subsection{Conclusion}

Many empirical studies have examined the influence of corruption on economic growth at the country level, but only a few have looked at the effects of the level of corruption on FDI inflows. The quality of institutions or level of corruption in the domestic country has the potential to attract foreign direct investment depending on whether the foreign firm can exploit its location advantage (Abotsi, 2015) within the existing institutions. As corruption cannot be completely eradicated, reducing it to a threshold that can be accommodated by investors must be the goal that African leaders endeavor to achieve. This threshold is referred to as the Tolerable Level of Corruption for Investment in this study. Using a dynamic panel data estimation technique while controlling for other variables, the estimated tolerable level of corruption in Africa is -0.27 on the control of corruption scale, which ranges from approximately -2.5 (weak) to 2.5 (strong). Since 2009, only 12 African countries had control of corruption scores equal to or above the TLCI. This means that the level of corruption in majority of African countries goes beyond merely receiving bribes to malfunction- 
ing of government institutions. Therefore, all African leaders and stakeholders, especially in countries that fall below the TLCI, should intensify their efforts in the fight against corruption to reduce the level of corruption in their respective countries to at least the TLCI to attract FDI to enhance their development. This TLCI will also guide potential investors in selecting which African countries to invest in.

This study's limitations result from the nature and availability of the data deployed in the study. The frequency of the data is annual, and it spans from 1996 to 2012 for 50 countries in Africa with data missing for three years (1997, 1999, \& 2001). More robust results would have been obtained if these data were available and included in the analysis. Another limitation to this study is the assumption that foreign investors choose a country based solely on the level of corruption of the host country because there are other country business risks and individual-specific shocks that investors take into consideration before an investment decision is made. It is recommended that in measuring corruption, researchers should endeavor to disaggregate corruption into its various components, such as bribes, kickbacks, and malfunctioning state institutions, because this will not only help stakeholders make informed decision in anticorruption policy formulation but also help them to know where to direct these policies.

\section{References}

Abotsi, A. K. (2015). Foreign Ownership of Firms and Corruption in Africa. International Journal of Economics and Financial Issues, 5 (3), 647-655.

Aizenman, J., \& Spiegel, M. (2002). Institutional efficiency, monitoring costs, and the investment share of FDI (Working Paper No. 9324). The National Bureau of Economic Research. Retrieved from http://www.nber.org/papers/w9324

Alsan, M., Bloom, D. E., \& Canning, D. (2006). The Effect of Population Health on Foreign Direct Investment Inflows to Low- and Middle-Income Countries. World Development, 34 (4), 613-630.

Anyanwu, J. C. (2012). Why Does Foreign Direct Investment Go Where It Goes ?: New Evidence From African Countries. Annals of Economics and Finance, 13 (2), 425-462.

Arellano, M., \& Bond, S. (1991). Some Tests of Specification for Panel Data: Monte Carlo Evi- dence and an Application to Employment Equations. Review of Economic Studies, 58 (2), 277-297.

Asiedu, E. (2002). On the Determinants of Foreign Direct Investment to Developing Countries: Is Africa Different? World Development, 30 (1), 107-119.

Asiedu, E. (2005). Foreign Direct Investment in Africa: The Role of Natural Resources, Market Size, Government Policy, Institutions and Political Instability. World Economy, 29 (1), 63-77.

Asiedu, E. (2013). Foreign Direct Investment, Natural Resources and Institutions (Working Paper). International Growth Centre. Retrieved from http:// www.theigc.org/wp-content/uploads/2014/09/ Asiedu-2013-Working-Paper.pdf

Asiedu, E., \& Lien, D. (2011). Democracy, Foreign Direct Investment and Natural Resources. Journal of International Economics, 84 (1), 99-111.

Baltagi, B. H. (2008). Econometric Analysis of Panel Data (4th ed.). Chichester, UK: John Wiley \& Sons Ltd.

Barassi, M. R., \& Zhou, Y. (2012). The Effect of Corruption on FDI: A Parametric and Non-Parametric Analysis. European Journal of Political Economy, 28 (3), 302-312.

Basu, S. R. (2008). A new way to link development to institutions, policies and geography. Retrieved from http://unctad.org/en/Docs/itcdtab38_en.pdf

Baum, F. C. (2006). An Introduction to Modern Econometrics Using Stata. College Station, TX: Stata Press.

Beck, N., \& Katz, J. N. (1996). Nuisance vs Substance: Specifying and Estimating Time-Series- CrossSectional Models. Political Analysis, 6 (1), 1-36.

Beck, P. J., \& Maher, M. W. (1986). A Comparison of Bribery and Bidding in Thin Markets. Economics Letters, 20 (1), 1-5.

Blundell, R., \& Bond, S. (1998). Initial Conditions and Moment Restrictions in Dynamic Panel Data Models. Journal of Econometrics, 87 (1), 115-143.

Bond, S. (2002). Dynamic Panel Models: A Guide to Micro Data Methods and Practice (Working Paper No. 09/02). Centre for Microdata Methods and Practise.

Botric, V., \& Škuflić, L. (2006). Main Determinants of Foreign Direct Investment in the Southeast European Countries. Ransition Studies Review, 13 (2), 359-377. 
Brahmasrene, T., \& Jiranyakul, K. (2001). Foreign Direct Investment in Thailand, What Factors Matter? Proceedings of the Academy for International Business, 1 (2), 13-25.

Cole, M. A., Elliott, R. J. R., \& Zhang, J. (2009). Corruption, Governance and FDI Location in China: A Province-Level Analysis. The Journal of Development Studies, 45 (9), 1494-1512.

Cuervo-Cazurra, A. (2006). Who Cares about Corruption? Journal of International Business Studies, 37 (6), 803-822.

Cuervo-Cazurra, A. (2008). Better the Devil You Don't Know: Types of Corruption and FDI in Transition Economies. Journal of International Management, 14 (1), 12-27.

Dal Bo, E., \& Rossi, M. A. (2007). Corruption and Inefficiency: Theory and Evidence from Electric Utilities. Journal of Public Economics, 91 (5-6), 939-962.

Dasgupta, D., \& Ratha, D. (2000). What Factors Appear to Drive Private Capital Flows to Developing Countries and How Does Official Lending Respond? (Policy Research Working Paper No. 2392). The World Bank.

Dauti, B. (2008). Determinants of Foreign Direct Investment inflow in South East European Countries - Panel Estimation (MPRA Working Paper No. 18273). University Library of Munich, Germany.

Dewenter, K. L. (1995). Do Exchange Rate Changes Drive Foreign Direct Investment? The Journal of Business, 68 (3), 405-433.

Dunning, J. H. (1973). The Determinants of International Production. Oxford Economic Papers, 25 (3), 289-336.

Dunning, J. H. (1980). Toward an Eclectic Theory of International Production: Some Empirical Tests. Journal of International Business Studies, 11 (1), 9-31.

Dunning, J. H. (1988). The Eclectic Paradigm of International Production: A Restatement and Some Possible Extensions. Journal of International Business Studies Issue, 19 (1), 1-31.

Dupasquier, C., \& Osakwe, P. N. (2006). Foreign Direct Investment in Africa: Performance, Challenges, and Responsibilities. Journal of Asian Economics, 17 (2), 241-260.

Efendic, A., Pugh, G., \& Adnett, N. (2009). Institutions and Economic Performance: System GMM
Modelling of Institutional Effects in Transition. European Journal of Political Economy, 27 (3), 586-599.

Egger, P., \& Winner, H. (2005). Evidence on Corruption as an Incentive for Foreign Direct Investment. European Journal of Political Economy, 21 (4), 932- 952.

Eicher,T.S.(1999). Trade, Development and Converging Growth Rates: Dynamic Gains from Trade Reconsidered. Journal of International Economics, 48 (1), 179-198.

Fedderke, J. W., \& Romm, A. T. (2006). Growth Impact and Determinants of Foreign Direct Investment into South Africa, 1956-2003. Economic Modeling, 23 (5), 738-760.

Fina, W., \& Rugman, A. M. (1996). A Test of Internalization Theory and Internationalization Theory: The Upjohn Company. Management International Review, 36 (3), 199-213.

Garibaldi, P., Mora, N., Sahay, R. and Zettelmeyer, J. (2002). What Moves Capital to Transition Economies? (Working Paper No. 02/64). International Monetary Fund. Retrieved from https://www.imf. org/external/pubs/ft/wp/2002/wp0264.pdf

Gastanaga, V. M., Nugent, J. B., \& Pashamiova, B. (1998). Host Country Reforms and FDI Inflows: How Much Difference Do They Make? World Development, 26 (7), 1299-1314.

Habib, M. \& Zurawicki, L. (2002). Corruption and Foreign Direct Investment. Journal of International Business Studies, 33 (2), 291-307.

Hakkala, K. N., Norback, P., \& Svaleryd, H. (2008). Asymmetric Effects of Corruption on FDI: Evidence from Swedish Multinational Firms. The Review of Economics and Statistics, 90 (4), 627-642.

Hoeffler, A. E. (2002). The Augmented Solow Model and the African Growth Debate. Oxford Bulletin of Economics and Statistics, 64 (2), 135-158.

Huntington, S. P. (1968). Political order in changing societies. New Haven, CT: Yale University Press.

International Labour Office. (2014). Global Employment Trends 2014 Risk of a jobless recovery? Global Employment Trends 2014. Risk of a jobless recovery? Geneva: International Labour Office. Retrieved from http://www.ilo.org/wcmsp5/groups/ public/---dgreports/---dcomm/---publ/documents/publication/wcms_233953.pdf 
Jadhav, P. (2012). Determinants of Foreign Direct Investment in BRICS Economies: Analysis of Economic, Institutional and Political Factors. Procedia - Social and Behavioral Sciences, 37, 5-14.

Javorcik, B. S., \& Wei, S. J. (2009). Corruption and Cross-Border Investment in Emerging Markets: Firm-Level Evidence. Journal of International Money and Finance, 28 (4), 605-624.

Jeon, B. N., \& Rhee, S. S. (2008). The Determinants of Korea's Foreign Direct Investment from the United States, 1980-2001: An Empirical Investigation of Firm Level Data. Contemporary Economic Policy, 26 (1), 118-131.

Johnson, A. (2006). The Effects of FDI Inflows on Host Country Economic Growth (Working Paper No. 58). The Royal Institute of technology. Centre of Excellence for studies in Science and Innovation. Retrieved from https://static.sys.kth.se/itm/wp/ cesis/cesiswp58.pdf

Kapsos, S. (2005). The Employment Intensity of Growth: Trends and Macroeconomic Determinants (Working Paper No. 2005/12). International Labour Organization.

Kersan-Skabic, I., \& Orlic, E. (2007). Determinants of FDI in CEE, Western Balkan Countries (Is Accession to the EU Important for Attracting FDI?). Economic and Business Review, 9 (4), 333-350.

Kyereboah-Coleman, A., \& Agyire-Tettey, K. F. (2008). Effect of Exchange-Rate Volatility on Foreign Direct Investment in Sub-Saharan Africa: The Case of Ghana. The Journal of Risk Finance, 9 (1), 52-70.

Lee, J. W. (1993). International Trade, Distortions, and Long-Run Economic Growth. IMF Staff Papers, 40 (2), 299-328.

Leff, N. H. (1964). Economic Development through Bureaucratic Corruption. American Behavioral Scientist, 8 (3), 8-14.

Leys, C. (1965). What Is The Problem About Corruption? Journal of Modern African Studies, 3 (2), 215-230.

Li, Q. (2009). Democracy, Autocracy, and Expropriation of Foreign Direct Investment. Comparative Political Studies, 42 (8), 1098-1127.

Lien, D. H. D. (1986). A Note on Competitive Bribery Games. Economics Letters, 22 (4), 337-341.

Lind, J. T., \& Mehlum, H. (2007). With or Without U? - The appropriate test for a $U$ shaped relationship
(MPRA Working Paper No. 4823). University Library of Munich, Germany.

Liu, X., Shu, C., \& Sinclair, P. (2009). Trade, Foreign Direct Investment and Economic Growth in Asian Economies. Applied Economics, 41 (13), 1603-1612.

Mateev, M. (2009). Determinants of Foreign Direct Investment in Central and Southeastern Europe: New Empirical Tests. Oxford Journal, 8 (1), 133-149.

Mauro, P. (1995). Corruption and Growth. Quarterly Journal of Economics, 110 (3), 681-712.

Musila, J.W., \& Sigue, S. P. (2006). Accelerating Foreign Direct Investment Flow to Africa: From Policy Statements to Successful Strategies. Managerial Finance, 32 (7), 577-593.

Mwilima, N. (2003). Foreign Direct Investment in Africa. Africa Labour Research Network Report. Retrieved from http://www.sarpn.org/documents/ d0000883/P994-African_Social_Observatory_PilotProject_FDI.pdf

Nerlove, M. (2002). Essays in Panel Data Econometrics. Cambridge: Cambridge, UK: Cambridge University Press.

Nickell, S. J. (1981). Biases in Dynamic Models with Fixed Effects. Econometrica, 49 (6), 1417-1426.

Nkurunziza, J. D. \& Bates, R. H. (2003). Political Institutions and Economic Growth in Africa (Working Paper 2003-03). Centre for the Study of African Economies. University of Oxford. Retrieved from http://econwpa.repec.org/eps/dev/ papers/0409/0409028.pdf

North, D. C., \& Weingast, B. R. (1989). Constitutions and Commitment: The Evolution of Institutional Governing Public Choice in Seventeenth-Century England. Journal of Economic History, 49 (4), 803-832.

Nunes, C. L., Oscategui, J., \& Peschiera, J. (2006). Determinants of FDI in Latin America (Working Paper No. 252). Department of Economics. Pontifical Catholic University of Peru. Retrieved from http://departamento.pucp.edu.pe/economia/images/documentos/DDD252.pdf

Piacentini, P., \& Pini, P. (2000). Growth and Employment. In M. Vivarelli, \& M. Pianta (Eds.), The Employment Impact of Innovation: Evidence and Policy (pp. 44-76). London, UK: Routledge. 
Picci, L. (2005, June). Corruption measurement and control: towards a unified approach. Paper Presented at IV Global Forum on Fighting Corruption, Brasılia.

Plassmann, F., \& Khanna, N. (2003). Assessing the Precision of Turning Point Estimates in Polynomial Regression Functions. Econometric Reviews, 26 (5), 503- 528.

Presbitero, A. F. (2005). The Debt-Growth Nexus: a Dynamic Panel Data Estimation (Working Paper No. 243). Department of Economics. Marche Polytechnic University.

Ranjan, V., \& Agrawal, G. (2011). FDI Inflow Determinants in BRIC Countries: A Panel Data Analysis. International Business Research, 4 (4), 225-263.

Roodman, D. (2006). How To Do xtabond2: An Introduction to "Difference" and "System" GMM in Stata (Working Paper No. 103). Center for Global Development. Retrieved from http://www.nuffield. ox.ac.uk/users/bond/file_HowtoDoxtabond8_ with_foreword.pdf

Roodman, D. (2007). A Short Note on the Theme of Too Many Instruments (Working Paper No. 125). Center for Global Development. Retrieved from http://www.cgdev.org/files/14256_file_Instruments.pdf

Roodman, D. (2009). How to do Xtabond2: An Introduction to Difference and System GMM in Stata. The Stata Journal, 9 (1), 86-136.

Sahoo, P. (2006). Foreign Direct Investment in South Asia: Policy, Trends, Impact and Determinants (Discussion Paper No. 56). Asian Development Bank. Retrieved from http://www.adb.org/sites/ default/files/publication/156693/adbi-dp56.pdf

Sarafidis, V., Yamagata, T., \& Robertson, R. (2009). A Test of Cross-Section Dependence for a Linear Dynamic Panel Model with Regressors. Journal of Econometrics, 148 (2), 149-161.

Sasabuchi, S. (1980). A Test of a Multivariate Normal Mean with Composite Hypotheses Determined by Linear Inequalities. Biometrika, 67 (2), 429-439.

Seyfried, W. (2005). Examining the Relationship between Employment and Economic Growth in the Ten Largest States. Southwestern Economic Review, $32,13-24$

Shleifer, A., \& Vishny, R. W. (1993). Corruption. Quarterly Journal of Economics, 108 (3), 599-617.
Svensson, J. (2005). Eight Questions About Corruption. Journal of Economic Perspectives, 19 (3), $19-42$.

Treisman, D. (2000). The Causes of Corruption: A CrossNational Study. Journal of Public Economics, 76 (3), 399-457.

UNCTAD. (2010). Investing in a Low-Carbon Economy. Retrieved from http://unctad.org/en/Docs/ wir2010_en.pdf

UNCTAD (2013). Global Value Chains: Investment and Trade for Development. Retrieved from http://unctad.org/en/ PublicationsLibrary/wir2013_en.pdf

Vial, V. \& Hanoteau, J. (2010). Corruption, Manufacturing Plant Growth, and the Asian Paradox: Indonesian Evidence. World Development, 38 (5), 693-705.

Voyer, P.A., \& Beamish, P. W. (2004). The Effect of Corruption on Japanese Foreign Direct Investment. Journal of Business Ethics, 50 (3), 211-226.

Vu, T. B., Gangnes, B., \& Noy, I. (2008). Is Foreign Direct Investment Good for Growth? Evidence from Sectoral Analysis of China and Vietnam. Journal of the Asia Pacific Economy, 13 (4), 542-562.

Wang, M. (2009). Manufacturing FDI and Economic Growth: Evidence from Asian Economies. Applied Economics, 41 (8), 991-1002.

Wei, S. J. (2000a). How Taxing is Corruption on International Investors. The Review of Economics and Statistics, 82 (1), 1-11.

Wei, S. J. (2000b). Local Corruption and Global Capital Flows". Brookings Papers on Economic Activity, 20 (2), 303-346.

Wijeweera, A., Villano, R., \& Dollery, B. (2010). An Econometric Analysis of Economic Growth and FDI Inflows. Economic growth and FDI inflows: a stochastic frontier analysis. Journal of Developing Areas, 43 (2), 143-158.

World Bank. (2013a). World Development Indicators. Washington, DC: World Bank.

World Bank. (2013b). Worldwide Governance Indicators. Washington, DC: World Bank. Retrieved from http://info.worldbank.org/governance/wgi/ index.aspx\#home

Yan, J. \& Oum, T. H. (2011). Effects of Government Quality and Institutional Choice on the Eficiency of the U.S. Commercial Airports. Available at http:// dx.doi.org/10.2139/ssrn.1956182 
Young, A. (1991). Learning by Doing and the Dynamic Effects of International Trade. Quarterly Journal of Economics, 106 (2), 369-405.

\section{Acknowledgements}

We are grateful to Professor Medhi Krongkaew (PhD) and Professor Piriya Pholphirul ((PhD) both of Graduate School of Development Economics, National Institute of Development Administration - Bangkapi, Thailand for their technical and practical advice. 